\title{
Gender Subversion in Iris Murdoch's The Unicorn
}

\author{
Soheila Farhani Nejad \\ English Department, Islamic Azad University, Branch of Abadan, Iran. \\ Email: soheila.farhani@gmail.com. ORCID: 0000-0001-8168-0703
}

\begin{abstract}
This study examines the various representations of female identity in Murdoch's The Unicorn. The analysis of the novel revolves around the character of Hannah who is the center of everyone's obsessive gaze. She is described both as an angel and a monster, a victim and a victimizer. Her victimization is aggravated by her passive submission to the will of her victimizers. This simultaneous presence of contradictory features in one character problematizes the notion of perceiving female identity in terms of binaries. As a typical Gothic heroine, Hannah is trapped within cultural assumptions about women. She passively and yet subversively plays the roles projected on her by the contradictory desires of other characters. It will be argued that the obsessive pursuit of perfection in a female figure as well as the disruption of the boundaries of victim and victimizer in this novel serve to problematize the cultural tendency to understand individuals in terms of stereotypes. Therefore, this study aims to illustrate how Murdoch has used an enigmatic female character to challenge the readers' disposition to perceive characters in terms of gender stereotypes.
\end{abstract}

Keywords: Gothic, Gender stereotypes, Binaries, Victimization.

\section{Introduction}

Gothic fiction has always attracted the attention of feminist critics as it serves to highlight the inherent problems within patriarchal societies. Issues such as the question of women subjugation to the tyranny of the patriarchal society, their rebellion against the will of fathers, brothers and husbands, and the consequences of their dissent feature greatly in many Gothic novels. In fact, the Gothic plot has proved to be inseparable from the question of gender, whether in practice or in theory. Considering the critical attention to the link between the Gothic form and gender-based interpretation, Murdoch's novels have been noted for their author's employment of what is often regarded a recurring motif in "the Female Gothic" plot, namely, the motif of an innocent female captivated in the hands of a brutal, egoistic male character: Hannah the sequestered beauty paying penance for a guilty adulterous past in The Unicorn (1963), Elizabeth, the self-enclosed niece/daughter, entrapped in an incestuous relationship with the demonic father- priest in The Time of the Angels (1966), the sexual and psychic entrapment of Rosa by the Polish brothers and later on by Mischa Fox, the enigmatic hero-villain, in The Flight from the Enchanter (1956) are some of the more obvious examples. Yet, one is struck by the way Murdoch's application of the "Female Gothic" formulas resists a sustained gender-based interpretation. After all, some of her entrapped females are far from stereotypical innocent victims of the traditional Gothic novels who in their efforts to flee the male tyranny, eventually manage to find and establish their place in the patriarchy. Murdoch's female captives can be manipulative, siren-like, and even diabolical. Their plight can hardly be used to make a final and essentialist statement about patriarchy's inherent disposition to enslave the female as the "other" as it is normally assumed to be the case. To address

(c) AesthetixMS 2021. This Open Access article is published under a Creative Commons Attribution Non-Commercial 4.0 International License (http://creativecommons.org/licenses/by-nc/4.o/), which permits non-commercial re-use, distribution, and reproduction in any medium, provided the original work is properly cited. For citation use the DOI. For commercial re-use, please contact editor@rupkatha.com. 
this inconsistency in character traits, this study attempts to investigate Murdoch's subversive use of Gothic gender stereotypes in The Unicorn (1963) by examining the problematic notion of identity of the main female character in this novel.

\section{Review of Literature}

One of the controversial issues for Murdoch's critics has been her application of Gothic conventions which tend to both propagate and frustrate reader's general tendency to approach her novels in terms of gender stereotypes. Many critics have pointed out that Murdoch's portrayal of female characters does not indicate the writer's feminist agenda in a revolutionary sense. Gary Goshgarian (1973) for example, argues that in most of her novels, Murdoch is not concerned with depicting the inferior position of women in the society but "the subtler effects of men building fantasies around women who are turned into an object for their projections" (p. 2). Leeson (2012) also contends that although in some of her novels Murdoch "decenters the female perspective", her approach to the question of gender is conflicted (p. 113). Reflecting the ambivalence in Murdoch's female characters, critics have conflicting views about Murdoch's depiction of female identity. For example, Emily Tait (2016) addresses the question of objectification of female characters in Murdoch's novels by arguing that very often the entrapped female characters resist the objectifying "Male gaze". This happens through "a more passive activity" on the female part. Some of Murdoch's female victims are given a "Medusa-like" quality that allows them to return the "gaze" (pp. 54- 55). Commenting on Felheim's assertion about the function of female characters in Murdoch's fiction as "puppets", Tait further argues that Murdoch has intentionally characterized her male characters as manipulators who try to turn female characters into "puppets" (2016, p. 54). Ming-ying XU (2014) believes that in discussing the notion of female identity in Murdoch's fiction we should note that according to Murdoch, "the formation of identity transcends a rigid gender boundary" (p. 162). Here, XU is referring to Murdoch's assertion that she prefers to deal with the question of female problem in her novels as an instance of human problem: "The women in my stories are - as the men are individuals with individual fates" (qtd in XU, p. 162).

Projection of male fantasies on women is a recurrent theme in Murdoch's fiction. This often leads to the loss of individuality on the part of female characters. Felheim (1960) for instance, complains that in Murdoch's fiction, characters particularly women possess no sense of identity, they are treated as "living symbols" (p. 189). The problematic notion of female identity in Murdoch's fiction becomes more complicated by the fact that in some of her novels, especially those in which the male point of view is dominant, female characters are endowed with the same duality at the heart of patriarchal society: as monstrous or angelic beings depending on the male fantasy. However, it is interesting to note that while female characters in her fiction are often described in terms of the victims of the patriarchal system, they can turn into victimizers and manipulators. Consequently, an important area of debate among the critics is the question of Murdoch's portrayal of female characters. This is mostly related to the dominant place of male characters in her novels. Margaret Rowe (2004) for instance, points out that Murdoch's novels are often told from the male point of view and in cases when there are no male narrators, "male characters and their psychological, ethical, and social dilemmas occupy center stage” (p. 8o).

Another recurrent Gothic trope in Murdoch's fiction is the motif of female captivity in the hands of male villains. This victimization is reinforced by the female characters' passivity and their apparent submission to the will of their victimizers. What is interesting in Murdoch's portrayal of these characters is that at times, the abuse takes the form of female idealization in the guise of romantic love. That is to say that in these novels, the male power figures pose as romantic lovers 
who impose their own notions of ideal feminine identity on their victims. This idea is particularly prominent in The Sea, The Sea. Weese (2001) has addressed this question by arguing that in this novel Murdoch has used Gothic elements to examine "the connection between the romance plot and the social construction of both masculinity and femininity" (p. 634). The narrator's obsessive concern with choosing a form for his narrative, his description of theater as a magical device for overpowering the audience, and the violence entailed in this description are also reflected in his treatment of Hartley, the lost love of his youth, and his consequent aggressive desire to turn her into the typical "heroine of a traditional love story" (Weese, 2001, p. 638). Reflecting the typical romance plot, that shares much with Gothic in terms of the heroine's passive suffering, and tyrannical fathers and husbands, Charles's version of Hartley's life story is based on his assumption that she is trapped in a loveless marriage with a monstrous husband and thus in need of rescue. Therefore, according to Weese, by portraying the male protagonist as the egocentric monster who endeavors to suppress and remold his fantasy of desirable femininity, Murdoch reverses the traditional formulas of "female Gothic" where the woman is typically personified as the "monstrous" entity (p. 638).

While the question of Murdoch's application of female Gothic formulas has been addressed by many critics, the main focus of most of these studies has been the ethical implications of Gothic tropes in her novels. The present study emphasizes the subversive nature of Gothic gender stereotypes in Murdoch's novels by focusing on the question of ambiguity in the character of Hannah in The Unicorn (1963), the enigmatic beauty who is entrapped in Gaze, a typical Gothic castle. She is treated both as a figure of feminine ideal and female monstrosity. As the analysis of Hannah's character will indicate, the way other characters try to understand her and the meaning of her story eventually turns her into a tabula rasa, an entity fitted into preconceived models to satisfy the others' expectations. My study argues that Murdoch's appropriation of Gothic tropes and gender conventions in The Unicorn in depicting the character of Hannah is subversive as it both encourages and neutralizes gender-based interpretation of characterization. To understand Murdoch's re-appropriation of gender conventions in this novel it is important to refer briefly to some of these conventions.

\section{Theoretical Framework: Gothic Conventions and Binary Oppositions}

Preoccupation with the nature of female identity is of seminal importance in Gothic fiction. As Horner and Zlosnik (2016) have asserted, Gothic writing reveals anxiety and even "anger" with regard to the question of woman and her position in the society (p. 1). This sense of anxiety is reflected in what Horner and Zlosnik (2016) call the "continued polarization of women through patterns of antithesis such as good/ bad, saint/sinner and virgin/whore; a continued use of stereotypes; and the pathologization of women who fail to conform to traditional expectations " ( $p$. 1). Consequently, an important motif in Gothic fiction is the use of binary oppositions in describing female characters. In most Gothic novels, female characters are divided into angels or monsters in terms of their submission to the norms of the society. The monstrosity of female characters is often associated with their sexuality, while their angelic nature is described in terms of virtue and purity. Some critics consider female monstrosity and the uncanny fear associated with the female body a result of the cultural construction of patriarchal order. Creed (1986) for example, ascribes this monstrosity to the question of "sexual difference and castration" as described by Freud (p. 44). The female body is signified by lack; the absence of penis leading to the type of difference "grounded in monstrousness" (Creed, 1986, p. 44). On the other hand, reflecting the importance of female reproductive system in the formation of the female psyche, the female body and mind are culturally 
linked to nature, purely biological, and hence devoid of rationality and conscious control. As Hurley (2004) explains, this accentuation of sexual difference has led to the cultural notion of female insanity. Nineteenth century medicine has described female body as essentially "pathological". Based on this view, women are considered "victims of periodicity", as Hurley mentions (p. 120). This is due to the stressful nature of "female life cycle" which has to go through the different stages of pregnancy, birthing, and menopause, exposing her to hormonal discharges that affect her both physically and psychologically (Hurley, 2004, p. 120). The cultural disposition to view the female as biologically flawed has led to a sharp demarcation in the way women are depicted in literature. Women are often viewed as either angels or monstrous beasts. This duality in the cultural notion of femininity and female sexuality is particularly manifested in the cultural tendency to dichotomize women into "mothers" and "prostitutes". As Chodorow (1994) says, based on the values of patriarchal societies, men are often expected to marry the same type of woman as their mothers, defined by virtue and holiness while at the same time, any thought of sexual attraction towards mothers is strongly forbidden. In contrast to the mothers who are endowed with holiness, sexually permissive women can be desired yet "they are maritally and socially forbidden" (p. 22).

The monstrous feminine as the embodiment of perverted sexuality stands in sharp contrast to the Victorian construction of the feminine ideal as the angel in the house. In The Madwoman In The Attic (1979), Gilbert and Gubar explore the way women have been "penned in" by male writers throughout the western culture based on the male perspective. Regarding the rise of the concept of the angelic female all through the eighteenth and nineteenth century, they have traced back the way young girls are culturally instructed to be obedient and selfless to accomplish the male constructed ideal of femininity. According to this ideal, a woman seems to have no story of her own; she lives for the man and for his betterment. Even the myth of creation of woman certifies her lack of autonomy: created out of man's ribs, she must lead a life of virtue as defined by the patriarchy. Otherwise, her self-assertiveness and her desire to live as she chooses will doom her to a life of "sacrilegious fiendishness" and monstrosity (Gilbert and Gubar, 2020, p. 28).

Another recurrent motif in Gothic fiction is the idea of female entrapment. Generally speaking, the plot of Gothic fiction reflects the traditional notions of female passivity and emotional vulnerability. As Ellis (1989) has asserted, the idea of female vulnerability requires the protective shield of an enclosed space, "the home". Yet this "home" can be turned into a place of danger, as embodied in the onerous form of the Gothic castle (p. xiii). The prevalence in Gothic fiction of female victims, their incarceration and their passive suffering has led the critics of Gothic fiction to the denunciation of the Gothic form for promoting the kind of ideology called "victim feminism". Some critics, on the other hand, are against the idea of Gothic novelists' complicity in creating and normalizing the notion of female victimization. These critics believe that Gothic texts enable writers to defy the stereotypical representation of women as victims. This idea has been explored by Hoeveler (1998) who proposes that female Gothic novelists often use the appearance of victimhood as a strategic device for female characters to attain some degree of control over their position in the patriarchy. In her preference for the term "professional femininity" instead of "victim feminism", Hoeveler (1998) explains this idea as "a set of literary masquerades and poses" and "a kind of gender construction" that has politically "subversive" implications (p. XII). According to Hoeveler (1998), the Gothic female characters' acceptance of their own victimization, their docility and willing adherence to do what is proper for a woman, can be interpreted in terms of "wise passiveness" or "a form of passive-aggression" (p. 7). Through this staged passivity, women are able to subdue and punish the male tyrants and contain the unruly Gothic villains in the enclosure of home in the conclusion of a perfect marriage based on equality. Thus, as Horner and Zlosnik (2016) have explained, Gothic writing "can be used to negotiate inherited, changing and often 
contradictory female identities rooted deep in the cultural imagination" (p. 11). One of the writers who has used the conventions of Gothic to challenge the validity of cultural gender stereotypes in understanding characters is Murdoch. In what follows I will discuss the way this tendency to understand others in terms of stereotypes can lead to the loss of a sense of identity and individuality. The novel I have selected for analysis is The Unicorn, Murdoch's full-fledged Gothic novel and my analysis revolves around the character of Hannah, her suffering and the other characters' attempt to romanticize the meaning of her story.

\section{Discussion}

In The Unicorn (1963), Murdoch has used Gothic conventions to address the question of female identity. The novel starts on a note of mystery and suspense, typical to the nineteenth century Gothic romances. Seeking the position of governess in the suggestively-named "Gaze Castle", Marian arrives at an unnamed village. She discovers, to her dismay, that the promised job is in fact nothing more than being a "lady companion" for the mistress of Gaze Castle, Hannah (Murdoch, 2001, p. 33). Hannah, a wealthy woman, has been victim of a marriage of convenience. Her husband, Peter, is consistently unfaithful to her and repeatedly cheats on her with both female and male lovers. Hannah falls in love with the neighbor's son, Philip and starts an affair. Eventually, Peter finds out about her adultery. Upon arriving home unannounced, he discovers Hannah with her lover. After a violent struggle, Hannah runs toward the cliffs and Peter follows her. Eventually, he falls off the cliff under suspicious circumstances and is maimed. Hannah, however, is blamed for the incident and is accused of attempting to kill her husband. After these events, Hannah, confined to the house and guarded by her purported jailers, first Gerald, and later on, two distant relatives, Jamesie and Violet, acquires a legendary status among the local people who believe if Hannah ever attempts to leave her prison house, "she will die" (Murdoch, 2001, p. 75). Now, at the time when the story starts, seven years have passed and according to the locals something is about to happen to Hannah.

Considering the abundance of Gothic paraphernalia in the novel, Hannah's plight can be read as designating her in the role of a conventional Gothic heroine entrapped in a castle. Critics such as Wallace (2009) have discussed the different elements of Gothic fiction in terms of a "series of inter-connected metaphors" (p. 29). Among these metaphors, Wallace refers to the Gothic castle and the metaphor of death and burial which have been commonly used by feminist critics to "explore and challenge representations of femininity" (p. 37). The house as a male construct is a burial place for the heroine. It is an embodiment of a culture which denies female "a full subjectivity" (Wallace, 2009, p. 38). In The Unicorn, this is highlighted in Hannah's incarceration in the family castle by her husband. Gaze Castle is an emblem of the patriarchy as is evident in the familial link between Hannah's husband and her father. Hannah is married to her cousin on her father's side and when she tries to run away from Gaze to take refuge at her father's house, he refuses to take her in. The implication here is that the same patriarchal principle dominates and controls both houses. There seems to be a pact between the father and the husband linking them to the same patriarchal order. This order demands that the wayward daughter should be disciplined and be led back to her rightful place, in the "house". Hannah's room is like a "shrine" (Murdoch, 2001, p. 28) and she is frequently associated with death. Her sleep-like condition denotes her deathin-life state of living. For Effingham, she is "a lamb led to the slaughter" (Murdoch, 2001, p. 247). Toward the end of the story, after Hannah kills Gerald, in her presence Marian feels she is facing "a mutilated corpse" (Murdoch, 2001, p. 226). Her skin is "inert and cold" as if she is already dead (Murdoch, 2001, p. 282). 
Generally speaking, the imprisonment of female characters in Gothic fiction reflects the traditional patriarchal notion of female mischievous nature. From this point of view, imprisonment is a way to control this wickedness. The notion of evil in female nature is often associated with sexuality. Based on this view, female sensuality, her curiosity and her role as a "sexual being" will not only bring about her own ruin but the destruction of those tempted by her natural wickedness (Williams, 1995, p. 105). According to Punter and Byron (2004), in many Gothic novels, the idea of transgression in the family is often "associated with the sensational spectacle of the mad or criminal female protagonist" (p. 27). The idea of madness of the female characters in Gothic fiction denotes cultural anxieties regarding the question of gender role and female identity. This idea is evident in Hannah's situation in The Unicorn. She is described as "ill, deranged, or in despair" (Murdoch, 2001, p. 51). The reason for her imprisonment which is referred to as her "sin", is her infidelity towards her husband. She is also considered as a sacrificial character. This ambivalent application of literary conventions and religious symbolism in the novel serves to expose the essential irrationality of cultural assumptions about female nature. For example, the tradition of courtly love is used to idolize Hannah's virtuous nature and physical beauty, while her silent submission to imprisonment is considered an acknowledgement of her sinfulness and her readiness to atone for her own sins and those of others including her husband. Hannah can also be "a sort of enchantress, a Circe, a spiritual Penelope keeping her suitors spellbound and enslaved" (Murdoch, 2001, p. 116), or "a fey, almost demonic creature"( Murdoch, 2001, p. 109). Violet calls her a "murderous, adulterous woman" (Murdoch, 2001, p. 214). The contradictory features of a saint and a sinner, however, can be both supported depending on the onlooker's perspective. Hannah is trapped within the cultural and literary assumptions about women. She, passively yet disruptively, plays the roles bestowed on her by the contradictory desires of other characters.

The name "Gaze Castle" places a double emphasis on the idea of entrapment. As the staple architectural enclosure for Gothic fiction, the castle typically incarcerates its inhabitants or any character who enters it. The psychoanalytic notion of "the gaze" as developed by Lacan, can be used to describe the way Hannah's entrapment in Gaze empowers the onlookers while it signifies Hannah's "otherness". As the lady of "the Gaze Castle", Hannah is the target of everybody's obsessive "gaze". Her reality is fixated in momentary acts of representation which deny her right to individuality. For seven years, she has managed to survive her plight by forgetting the passage of time. She lives for the momentary pleasures of eating, drinking and dressing up for dinner parties. Almost everyone in the novels treats her as a beautiful object. She seems to exist for the purpose of satisfying the other characters' idealistic fantasies and their delight in myth and legend.

Hoeveler's idea (1998) that the tradition of "female Gothic" has contributed to the development of "illusory, often self-destructive forms of [female] idealization" (p. XVI) is best expressed in Murdoch's particular application of the conventions of Gothic fiction in The Unicorn. Hannah's incarceration in her prison house expresses the ethical drawbacks of a culture which, at best, promotes the idea of passive suffering for the female as a better alternative to open acts of rebellion. For Marian, she looks like "some brave beleaguered lady in a legend or some painter's dream” (Murdoch, 2001, p. 60). Effingham, Hannah's courtly admirer, regards her as "the great phoenix", his "Beatrice", "the chaste mother-goddess, the Virgin Mother", (Murdoch, 2001, p. 275) "a great placid golden idol" (Murdoch, 2001, p. 103). These epithets reflect the way patriarchal culture, in Goshgarian's words, attempts to "reduce the meaning of a woman to a mythic model" (1973, p.169). Murdoch's critical stance toward this idealization of a female figure, is concealed behind the philosophical interpretation of Hannah's meaning. The ambiguity in her character and her exaltation to the status of a goddess further, satirizes reader's general tendency to read a character symbolically. Hannah is mostly referred to in terms of her body parts, particularly her 
face: "big golden eyes", "sleepy face”, "anxious tired beautiful defeated golden-eyed face” (Murdoch, 2001, p. 63). This reduction of a character into body parts suggests the fetishization of femininity in Petrarchan love poems in which the idealized beloved is praised for what is traditionally regarded as the image of ideal female beauty: "golden eyes", "coral lips" and etc. Murdoch's novels often reflect this cultural tendency to "objectify" women through what Tait (2016) calls "voyeuristic description with scopophilic intensity" (p. 56). In the patriarchal signifying system which constructs the background of the story, Hannah is entrapped in a chain of signifiers. As befits her symbolic status in the story, she functions as a text to be read and contemplated. This tendency is reflected in Marian and Effingham's constant efforts to read her facial features. Thus, as Effingham contemplates her beauty, he wonders about what is "written on that brow, something about suffering: only he could not read the characters" (Murdoch, 2001, p. 124).

While the image of darkness in Gothic novels often contributes to the creation of Gothic ambience, the interaction of the images of light and darkness in The Unicorn serves to problematize the idea of creating meaning based on traditional models. In the manner of other Gothic heroines, Marian should figure out how to make her way out in the house's dark interior. She is often described in terms of entering some dark place. Except for Hannah's room, the other parts of Gaze are engulfed in darkness, which leads the other characters to seek enlightenment in her presence. Hannah's room, however, is overly lighted, while the curtains are drawn even in daytime. Hannah is shut off from the outside world in her "shrine"-like room, while "the line of golden lights" which leads to her room suggests the gateway to a martyr's temple (Murdoch, 2001, p. 28). Hannah's imprisonment is regarded as some kind of sacrifice for her own sins and those of the other characters. As Denis, one of the characters in the novel, says, in Gaze Castle "everyone ...is involved in guilt" (Murdoch, 2001, p. 157). They are all afflicted by an obsessive pursuit of spirituality. Conradi (2001) has aptly called Gaze "an erotic prison masquerading as a place of religious retreat" (n. p). It is ironic that the temple enshrines a fake religious icon who has to depend on her "whiskey" to sustain that delusion for herself and for the others. That is why she is constantly serving her visitors with that "familiar and disturbing" potion (Murdoch, 2001, p. 105).

It is interesting to note that despite her incarceration in a Gothic castle Hannah cannot be perceived as a stereotypical innocent victim of the traditional Gothic novels. This is mainly due to Hannah's complicity in her own incarceration. Despite all the other characters' concern with her captivity, Hannah does not show any interest in changing the status quo. Hannah's submission to imprisonment can be explained in terms of Hoeveler's view (1998) of "professional femininity" which argues that in Gothic fiction, female characters accept their roles as victims to exercise some kind of control over their victimizers (p. 4). These characters pose as "professional girl-women caught up in an elaborate game of playacting for the benefit of an obsessive and controlling male gaze" (Hoeveler, 1998, p. 4). This idea is evident in the fact that Hannah derives her power over the other characters through her own passive victimization and acceptance of the roles projected on her by her jailors. This sense of empowerment can nonetheless be illusory as is indicated in the disruption of the boundaries of victims and victimizers.

Goshgarian (1973) describes Hannah's character in terms of a "dark parody". Her "literary dehydration, [and] her flattened stereotypes" are the writer's deliberate strategies to highlight the ills of cultural tendency to deny a woman's reality (p. 167). Murdoch has seemingly intended her to be as "obscure and undeveloped" as she appears to be all through the story (Goshgarian, 1973, p. 167). Her representational quality, her indeterminacy, is highly disturbing for the reader for the very reason that she is being constantly re-read and re-created by other characters based on their fantasies. Hannah is represented to the reader as "the plethora of romantic epithets her various 
worshipers substituted for [her] being" (Goshgarian, 1973, p.169). As the lady of "the Gaze Castle", she is the target of everybody's obsessive "gaze"; her reality is fixated in momentary acts of representation which deny her right to individuality. The ambiguity in her characterization, additionally, suggests the universal fact that individuals lose their own reality when they are turned into stereotypes or mere representations of ideas. Her dilemma is whether to regain her own sense of coherent self or allow herself to be turned into a multi-dimensional symbol. The fact that Hannah was drawn to the latter option, signifies the vulnerability and the unstable nature of the notion of coherent self, when constructed through diverse cultural codes and literary clichés.

\section{Conclusion}

Therefore, as can be seen, Hannah is an instance of a character with no boundaries of selfhood. As the focus of other characters' obsessive desire, she is depicted as both a Christ figure and a manipulative power figure. Her situation is constantly discussed by the other characters in terms that only accentuate her incomprehensibility. On the one hand, religio-cultural stereotypes modelled on Christianity and cultural construction of gender, point to her position as a sacrificial character. On the other hand, she can also be a manipulator. Interestingly, Murdoch's narrative offers no closure to the enigma of the meaning of Hannah's suffering. The reader is eventually left with Hannah's statement of her own duplicity: "I had lived on my audience, on my worshippers. I have lived by their thoughts, by your thoughts- just as you have lived by what you thought were mine. And we have deceived each other" (Murdoch, 2001, p. 258).

Hannah's liminality is reflected in various concurrent views about her story and the meaning of her suffering. The other characters fall into the error of investing her suffering and imprisonment with a surfeit of meaning. As she confesses by the end of the story, she lives for the sake of satisfying the other characters' fantasies. The textual clues point to her guilt as well as her suffering. This simultaneous presence of contradictory traits poses the problem of interpretation as it serves to highlight the problematic nature of perceiving individuals in terms of culturally male or female, based on the gender assumptions of patriarchal societies. Thus, the ambivalence in Hannah's character reflects Murdoch's delibrate subversion of the conventional representation of femininity in Gothic fiction.

\section{References}

Chodorow, N. J. (2009). Femininities, Masculinities, Sexualities: Freud and Beyond: University Press of Kentucky.

Conradi, P. J. (2001). The Saint and the Artist: a Study of the Fiction of Iris Murdoch: HarperCollins UK.

Creed, B. (1986). Horror and the Monstrous-feminine: An Imaginary Abjection. Screen, 27(1), 44-71.

Ellis, K. F. (1989). The Contested Castle: Gothic Novels and the Subversion of Domestic Ideology: University of Illinois Press.

Felheim, M. (1960). Symbolic Characterization in the Novels of Iris Murdoch. Texas Studies in Literature and Language, 2(2), 189-197.

Gilbert, S. M., \& Gubar, S. (2020). TheMadwoman in the Attic: The Woman Writer and the Nineteenth-century Literary Imagination: Yale University Press.

Glennis, B., \& David, P. (2004). The Gothic: Oxford: Blackwell. 
Goshgarian, G. (1973). From Fable to Flesh: a Study of the Female Characters in the Novels of Iris Murdoch. (P.h.D diss), University of Wisconsin.

Hoeveler, D. L. (1998). Gothic Feminism: The Professionalization of Gender from Charlotte Smith to the Bront's: Penn State Press.

Horner, A., \& Zlosnik, S. (2016). Women and the Gothic: an Edinburgh companion: Edinburgh University Press.

Hurley, K. (2004). The Gothic Body: Sexuality, Materialism, and Degeneration at the fin de siècle: Cambridge University Press.

Leeson, M. (2012). The Engendered and Dis-engendered Other in Iris Murdoch's Early Fiction. In R. K. a. C. Westall (Ed.), Cross-Gendered Literary Voices (pp. 113-127), London: Palgrave Macmillan.

Murdoch, I. (2001). The Unicorn: London: Penguine Books.

Rowe, M. M. (2004). Iris Murdoch and the Case of" too Many Men". Studies in the Novel, 36(1), 79-94.

Tait, E. (2016). " Seething Underneath": Objectification in Iris Murdoch's Early Fiction. Journal of International Women's Studies, 17(2), 54-64.

Wallace, D. (2009). 'The Haunting Idea': Female Gothic Metaphors and Feminist Theory. In Diane Wallace and Andrew Smith (Eds.), The Female Gothic (pp. 26-41), Springer.

Weese, K. L. (2001). Feminist Uses of the Fantastic in Iris Murdoch's The Sea, the Sea. Modern Fiction Studies, 47(3), 630-656.

Williams, A. (1995). Art of Darkness: a Poetics of Gothic: University of Chicago Press.

Xu, Ming-ying. (2014). The Establishment of Female Identity in The Black Prince. American International Journal of Social Science, 3, 161-167.

Soheila Farhani Nejad is a lecturer at the English Department of Islamic Azad University, Branch of Abadan, Iran. She has a Ph.D in English Literature from the University of Science, Malaysia (USM). Her main areas of research interest include contemporary fiction, structuralism and psychoanalysis. 